\title{
The Evidence and Gap about the Relationship between International Diversification and Performance
}

\author{
Hang $W U^{1, a,{ }^{*}}$ \\ ${ }^{1}$ Business School, East China University of Political Science and Law, \\ Shanghai 201620, China \\ awuhang0503@163.com
}

Keywords: International diversification, Performance, Intermediary mechanism, Relationship type.

\begin{abstract}
There are many scholars who believe that there is a positive correlation relationship between international diversification and firm performance. However, some scholars have found that international diversification has a negative, U-shaped, inverted U-shaped and S-type relationship with firm performance. The reason for this is that the impact of international diversification on financial performance is a complex process, and knowledge acquired from international markets does not directly affect corporate financial performance, but rather has an impact on product innovation and process innovation or capability enhancement. Therefore, further research can explore the impact of international diversification on innovation, or examine the intermediary mechanism between international diversification and performance.
\end{abstract}

\section{Introduction}

Research on the relationship between international diversification and performance is a hot issue in strategic management and international business. Through the literature review, it can be found that research in this field has achieved fruitful results, but the relationship between international diversification and performance is still controversial. Early studies focused on the performance differences between international and domestic firms only. Later studies began to focus on the relationship between internationalization and financial performance. Vernon [1] argues that a positive correlation between internationalization and firm performance because of economies of scale and location-specific advantages, and this view stimulates a positive correlation between internationalization and performance in the 1970s and 1980s.

Even recently, there are scholars who believe that there is a positive correlation between internationalization and firm performance. However, some scholars have found that international diversification is negatively correlated or not significantly related to firm performance. In addition, scholars have proposed a U-shaped relationship between international diversification and firm performance, inverted U-shaped relations and S-type relationships, which reflect the costs and benefits of internationalization.

\section{Measurement of International Diversification}

Measurements of international diversification of existing literature reflect one or more aspects of the international operations, ownership, and international orientation [2]. At present, scholars have not formed strict and consistent standards on the measure of international diversification. They can be summarized into the following three 
categories: single-dimension single index, multi-dimensional composite index, multi-dimension multi-index [2].

\section{Single-dimension Single-index Measurement}

At present, from the perspective of operational performance or operation structure, most scholars choose the proportion of foreign sales to total sales (FSTS), the proportion of foreign assets to total assets (FATA), the ratio of export sales to total sales and the total operating income outside the country, the number of overseas subsidiaries, the proportion of overseas assets or the number of exporting countries to measure international diversification [2]. For example, the proportion of foreign sales to total sales reflects the extent to which a firm's sales income depends on overseas markets. The proportion of foreign assets to total assets reflects the extent to which firms depend on overseas production. The number of overseas subsidiaries, based on regional sales figures, is based on various factors, can reflect the degree of decentralization of location costs and benefits [3].

\section{Multi-dimensional Composite Index Measurement}

Some researchers argue that a single indicator can't reflect the multidimensional characteristics of internationalization and proposes five indicators to measure the international diversification from the three dimensions of performance, structure and attitudes. The World Investment Report 2000 published by the United Nations Conference on Trade and Development (UNCTAD) uses the average of the three indicators FATA, FSTS and FETE as the measure of international diversification. Lu and Beamish [4] use the average of NOS and NCOS as indicators of international diversification. Gomes and Ramaswamy [3] use principal component analysis to integrate several indicators of FSTS, FATA, NCOS, FETE into a single index to measure international diversification.

\section{Multi-dimensional Multi-index Measurement}

Goerzen and Beamish [5], for the first time, decompose international diversification into two dimensions: the extent to which firms' international assets are fragmented and the diversity of countries involved, each dimension being made up of a number of indicators. The extent of international asset diversification reflects the distribution breadth of value-added activities of multinational companies, while the diversity of countries reflects the complexity of the operating environment of multinational corporations.

\section{The Relationship between International Diversification and Firm Performance}

\section{Positive Relationship}

Traditional theory of foreign direct investment (FDI) has laid a solid foundation for understanding the mode and mechanism of enterprise internationalization. The most influential FDI theory is internalization theory and eclectic theory. The core idea of internalization theory comes from Coase's transaction cost theory and Penrose's firm growth theory. According to the internalization theory, in the face of market imperfections (such as information asymmetry, government intervention, etc.), enterprises will internalize the intermediate market (such as intangible assets market) across national borders. In this way, firms are able to achieve economies of scale and economies of scale. Dunning's eclectic theory is based on a variety of FDI theories. In 
addition to the advantages of internalization and intangible assets, location advantage is also important for internationalization of enterprises, and the specific location advantage can bring development opportunities and resource endowments to enterprises.

This view stimulated the study of the positive relationship between international diversification and performance in the 1970s and 1980s [1]. Even in recent years, there are scholars who argue that, in addition to their unique competitive advantage in international markets, firms can diversify their business risks by internationalizing their organizational learning and gaining complementary resources to enhance their competitive advantage [6]. Therefore, the traditional internationalization theory supports the positive influence of international diversification on enterprise performance. A large number of empirical studies also confirm the positive correlation between internationalization and firm performance.

\section{Negative Relationship}

Although both internalization theory and eclectic theory acknowledge the additional costs of internationalization, they are of little concern because traditional internationalization theory assumes that firms have accumulated certain advantages prior to internationalization to overcome international disadvantages. However, empirical research shows that the cost of internationalization has negative effects on firm performance, including liabilities of foreignness, liabilities of newness, financial and political risks of international operation, internal coordination and incentive costs [4]. It is worth noting that financial scholars pay much attention to internationalization costs, focusing on international risks, financial transaction costs, investor internationalization awareness, and treat risk-adjusted returns and stock market value as a measure of corporate performance indicators. A large number of empirical studies provide evidence of the existence of international disadvantages [7] [8]. For example, Michael and Shaked [7] use risk-adjusted rate of return as an indicator to measure corporate performance, conduct a comparison between the United States 58 international companies and 43 domestic enterprises, and find that the performance of international enterprises was significantly lower than the domestic business enterprise. Denis and Yost [8] take the stock premium and its fluctuation as the evaluation index of enterprise performance, and FSTS as the measure of internationalization degree, confirm that with the deepening of internationalization, the market value of internationalized enterprises will decline compared with domestic enterprises. In addition, some other scholars have confirmed the internationalization of the negative impact on business performance

\section{Reverse U Relationship}

As the international performance of enterprises is dynamically influenced by international income and cost, so some scholars believe that the degree of internationalization and business performance is not a simple linear relationship between. Based on the Uppsala model of Johanson and Vahlne [9], these scholars think that internationalization is a gradual process. In the early days of internationalization, firms often enter a country that is similar to their home country's business environment, minimizing international disadvantages, resulting in economies of scale and location advantages, and then firms move into heterogeneous international markets [10]. Complex environments and organizations make the cost of information management and coordination increase drastically, and the marginal cost of internationalization 
surpasses the marginal revenue of internationalization. Therefore, the degree of internationalization and performance of enterprises was inverted U-shaped relationship; corporate performance reaches the maximum in a certain international level, after reaching the international inflection point decreased. A number of empirical studies have also confirmed the inverse relationship between internationalization and firm performance.

\section{U Relationship}

In contrast to the inverted U-type hypothesis, some scholars argue that internationalization and performance are U-shaped relations, and their theoretical footholds emphasize the external disadvantages of the early stage of internationalization rather than the later coordination costs and management costs of internationalization. Lu and Beamish [11] argue that, unlike large firms, SMEs lack the international experience and knowledge in the early stages of internationalization and are unable to overcome the institutional and environmental constraints of international operations. Thus, in the early stages of internationalization, international diversification has negative correlation with enterprise performance. Through empirical learning and accessing to resources, growth of new knowledge and ability makes enterprise performance improve. A longitudinal study of large German manufacturers by Ruigrok and Wagner [12] also confirms the U-shaped relationship between international diversification and firm performance. Ruigrok and Wagner [12] argue that, unlike the internationalization of US firms, German firms often enter into countries with far-reaching institutional distances in the early stages of internationalization and are therefore limited by the external environment. Only after adjusting the internal systems, mechanisms and processes, firms can adapt to the international environment and promote the improvement of corporate performance. A large number of empirical studies also confirm the U-shaped relationship between internationalization and firm performance.

\section{S Relationship}

In view of the U-shaped relationship and the inverted U-shaped relationship between internationalization and enterprise performance, some scholars have tried to integrate the two viewpoints and put forward the horizontal S-type relationship model between internationalization and enterprise performance. Among them, the most representative is Contractor et al. [13], Lu and Beamish [4] of the three-stage model. In the early stage of internationalization, enterprises are not familiar with foreign markets and culture due to liabilities of foreignness and liabilities of newness. As a result, the cost of learning is high, and the early internationalization of enterprises is generally small. Internationalization has a negative impact on enterprise performance. When the internationalization of enterprises reaches a certain level, enterprises can effectively reduce the cost of internationalization through learning and study, and then internationalization has a positive impact on enterprise performance. When the internationalization of enterprise develops to the advanced stage, at this time the marginal cost of internationalization is higher than that of marginal revenue, while the cost of coordination and management costs of firms increase drastically. Therefore, the degree of internationalization of enterprises and enterprise performance was horizontal S-shaped curve. Contractor et al. [13] testified the hypothesis of the horizontal S-type relationship between the degree of internationalization and firm performance in the service firm. Lu and Beamish's [4] empirical studies of 1489 Japanese firms also test 
the horizontal S-type relationship between firm internationalization and firm performance.

\section{The Intermediary Mechanism of International Diversification and Performance}

Since there is no unanimous conclusion on the relationship between international diversification and enterprise performance, some scholars have begun to study the intermediate process of internationalization impacting enterprise performance in an attempt to open the intermediate black box of international diversification and enterprise performance. Process variables such as organizational learning and operational improvement are useful for understanding the relationship between international diversification and performance. Researchers argue that through progressive internationalization, firms can learn from their own experience and other firms, thereby facilitating entry into unrelated product markets. Zahra et al. [14] found that internationalization can promote the depth, breadth and speed of technology learning in start-ups, and promote innovation, differentiation and market responsiveness through technology learning, and ultimately improve enterprise performance. Yeoh [15] found that geographic diversification of exports has a negative impact on technology learning, has no significant impact on market learning, and has a positive impact on social learning. Future research can further explore the contextual factors that enterprises learn from internationalization.

\section{Conclusion}

Through the literature review, we can find that scholars in the field of international business and strategic management have paid great attention to the consequences of international diversification, have formed an integrated research framework, but there is still a place worth further exploration.

First of all, the current research on international diversification of enterprises mainly concentrated in developed countries, for developing countries, the internationalization of enterprises is still in the exploratory stage, and need more research to contribute to it. International business theory originated from the study of transnational corporations in developed countries, its theoretical framework and research conclusions are based on enterprises in developed country. However, there are significant differences in the ownership and institutional environment between the enterprises of the developing countries and the enterprises of the developed countries in the international motive and mode. Therefore, the study of the internationalization of enterprises in developing countries can further verify and perfect the theory of internationalization.

Secondly, there is no conclusion on the relationship between international diversification and firm performance. The reason is mainly because the scholars have different understanding of international diversification and enterprise performance. At present, international diversification is mainly based on single-dimensional indicators, such as FSTS, FATA and other indicators, future research can consider multi-dimensional measurement of international diversification. In addition, measures of corporate performance are based on accounting and market-based financial measures, such as return on assets (ROA), sales rate of return (ROS), and so on. However, the impact of international diversification on corporate financial performance is a complex process. For example, knowledge acquired from international markets does not directly affect corporate financial performance, but rather has an impact on product innovation 
and process innovation. In particular, for firms in developing countries, a significant feature of the internationalization of these firms is the acquisition of technological assets or learning opportunities, which can directly affect enterprise innovation. Therefore, the future research may consider the innovation performance as the result variable, and study the influence mechanism of the international diversification on innovation performance.

\section{Acknowledgement}

This research was financially supported by the National Natural Science Foundation of China (71502064).

\section{References}

[1] R. Vernon, Sovereignty at bay: The multinational spread of U.S. enterprises. New York: Basic Books. 1971.

[2] M. Annavarjula, S. Beldona, Multinationality-performance relationship: A review and reconceptualization, The international journal of organizational analysis. 8(2000) 48-67.

[3] L. Gomes, K. Ramaswamy, An empirical examination of the form of the relationship between multinationality and performance, Journal of International Business Studies. 30(1999) 173-188.

[4] J. W. Lu, P. W. Beamish, International diversification and firm performance: The S-curve hypothesis, Academy of Management Journal. 47(2004) 598-608.

[5] A. Goerzen, P. Beamish, Geographic scope and multinational enterprise performance, Strategic Management Journal. 24(2003) 1289-1306.

[6] A. Delios, P. W. Beamish, Geographic scope, product diversification and the corporate performance of Japanese firms, Strategic Management Journal. 20(1999) 711-721.

[7] A. Michael, I. Shaked, Multinational corporations vs. domestic corporations: Financial performance and characteristics, Journal of International Business. 18(1986) 89-100.

[8] D. J. Denis, D. K. Denis, K. Yost, Global diversification, industrial diversification and firm value, Journal of Finance. 57(2002) 1951-1961.

[9] J. Johanson, J. E. Vahlne, The internationalization process of the firm: A model of knowledge-development and increasing foreign market commitments, Journal of International Business Studies. 8(1977) 23-32.

[10] Ramaswamy, K. Multinationality, configuration, and performance: A study of MNEs in the U.S. drug and pharmaceutical industry, Journal of International Management. 1(1995) 231-253.

[11] J. W. Lu, P. W. Beamish, The internationalization and performance of SMEs, Strategic Management Journal. 22(2001) 565-586.

[12] W. Ruigrok, H. Wagner, Internationalization and performance: An organizational learning perspective, Management International Review. 43(2003) 63-83. 
[13]F. J. Contractor, S. K. Kundu, C-C. Hsu, A three-stage theory of international expansion: The link between multinationality and performance in the service sector, Journal of International Business Studies. 34(2003) 5-18.

[14] S. A. Zahra, R. D. Ireland, M. A. Hitt, International expansion by new venture firms: International diversity, mode of market entry, technological learning and performance, Academy of Management Journal. 43(2000) 925-950.

[15]P. L. Yeoh, International learning: Antecedents and performance applications among newly internationalizing companies in an exporting context, International Marketing Review. 36(2004) 20-28. 